\title{
Food production and gender relations in multifunctional landscapes: a literature review
}

\author{
Lisa Westholm (1D) Madelene Ostwald
}

Received: 22 December 2017/ Accepted: 29 April 2019/Published online: 3 May 2019

(C) The Author(s) 2019

\begin{abstract}
High expectations are put to multifunctional land use systems that they can provide solutions to the increasing global demand for land and food. In this literature review, we ask whether multifunctional landscapes hold specific opportunities for women in enhancing food production and security in a context of gender inequality guided by a framework of access to productive resources and commercialisation. We review 104 scientific articles dealing with food production and security in a range of multifunctional land use systems across Africa, Asia and Latin America, including agroforestry, homegardens, livestock systems and urban agriculture. We find that the specific role of a landscape's multifunctionality for women's opportunities to enhance food security, is rarely explicitly examined in scientific literature. Our review shows that in a multifunctional setting, the products controlled by women are often secondary and far from markets, and therefore they risk being ignored in decision-making or by policy makers. Further, efforts to increase the value of traditionally "female
\end{abstract}

L. Westholm $(\bowtie)$

Department of Urban and Rural Development, Swedish

University of Agricultural Sciences, PO Box 7012,

75007 Uppsala, Sweden

e-mail: lisa.westholm@gmail.com

M. Ostwald

Centre for Sustainable Development (GMV), University of Gothenburg and Chalmers University of Technology, PO Box 170, 40530 Göteborg, Sweden products" risk having adverse effects on women's empowerment, in cases where powerful actors take over all or parts of the value chain, or appropriate the benefits. To remove these barriers traditional gender roles have to change. However, the instability of gender relations can also work in women's favour in a multifunctional landscape where several products and production systems exist, providing opportunities to claim new roles or resources, especially in the context of changing external circumstances, such as urbanization, a shift from pastoralism to sedentary livelihoods, or an expansion of the monetary economy.

Keywords Women · Value chains · Food production $\cdot$ Access $\cdot$ Productive resources

\section{Introduction}

Multifunctional landscapes or land use systems simultaneously support habitat, productive, regulatory, social and economic aspirations (Mander et al. 2007). Examples of multifunctional landscapes include agroforestry systems, homegardens, and integrated cropping systems. Some argue that wellmanaged multifunctional land use systems can promote win-win solutions for climate change mitigation and adaptation capacity, while intensifying production and enhance food security in a sustainable way 
(Bustamante et al. 2014; Mbow et al. 2014). However, there are also challenges involved in the management of multifunctional landscapes. They comprise a combination of product outputs and services, both private and public. These products and services can have different time frames, and benefit a range of stakeholders with varying rights, access, and power over decision-making related to resources and management. This means that there may be trade-offs between different interests.

In this literature review we ask whether there is evidence in the literature that multifunctional landscapes can provide more opportunities for women to ensure their own and their families' food security. We review research and findings relating to the resources and activities commonly available to women in relation to the production of food, and provision of food security in multifunctional landscapes. Based on this review, we examine the nexus of gender and multifunctional landscapes guided by the following research question: how do gender roles affect women's access to productive resources and to commercialisation/marketization resources related to food security and production? We further ask where the main opportunities for women lie, as well as what the greatest obstacles are, and how they could be overcome. Finally, we discuss how policy-makers can take into account the interests of women, and pay heed to gender relations when dealing with the trade-offs involved in managing multifunctional landscapes.

\section{Theoretical framework}

The entry point to the analysis is food security including the four main dimensions of availability, access, utilization and stability (FAO 2008). In our review of the literature, and attempt to answer the questions above, we draw on a number of theoretical concepts. One of these concepts is "access", which we discuss in the context of access to resources of varying kinds. Our definition of access is taken from Ribot and Peluso (2003), who define it as "the ability to derive benefit from things". This definition looks not only on who has the right, formal or otherwise, to a resource, but also at who has the power and ability to benefit from it. Similarly, Kabeer (1999) notes that women's empowerment, meaning the process whereby those previously denied the ability to make choices acquire such ability, requires not only that they are allocated resources, but also the agency and ability to make strategic choices around these resources.

The focus of the review lies on the role of women in the production of food, and enhancement of food security. However, we consider the constraints faced by women as produced by gender relations. Gender, as a theoretical concept, is an analytical category referring to "the social roles and identities associated with what it means to be a man or a woman in a given society and context" (Quisumbing et al. 2014: 6). Importantly, these roles are produced and given meaning in relation to each other, and must therefore be analysed as such. However, in relation to agriculture and food production, the focus has often been on men, meaning that a focus on women can help balance this, and thereby lead to greater gender equality. Our focus on women in this paper is done with an awareness of how their roles, responsibilities, opportunities and constraints are produced in relation to men, and at the intersection of multiple categories of social relations.

In exploring the role of women in food production, and the distribution of resources, it is important to keep in mind that the existence of gender roles and divisions of resources and labour does not imply that men and women work within separate and discrete production systems. Rather, to the extent that they belong to the same household/family unit, production systems are more often than not integrated, and/or connected. However, their ability to benefit and make decisions about the allocation of resources and benefits differs. Economic theory has struggled to conceptualise the distribution of resources within households using concepts such as welfare maximisation and rationality (Kabeer 1991). Such theorisation has received extensive criticism for treating households as a single entity maximising a joint welfare function (Agarwal 1997; Kabeer 1991; Sen 1990).

In order to tackle some of the problems with this type of unitary models for household decision-making, others have suggested conceptualising resource allocation within the household as a process of bargaining, where bargaining power is assumed to depend upon a person's fall-back position or outside option, such as how well off they would be if cooperation failed and they were to leave the household (Agarwal 1997; Doss 2013). However, the 
restrictions imposed in economic models of household bargaining have received criticism by feminist researchers for being too simplistic and ignoring the complex web of power, social and cultural norms and preference formation that shape intra-household relations and the incentives for cooperation and conflict (Agarwal 1997; Elson 1993; Kabeer 1991).

In our analysis of the literature, we have divided the resources necessary to ensure food security into two main categories-productive resources and marketization resources. Food security issues are more closely connected with production than marketization, and, consequently, the productive resources are more extensively discussed in the literature, as well as in our review. The productive resources include land, labour, and capital, in economic theory also known as the 'factors of production'. Human resources are not included in the analysis, partly due to their relative absence from the literature that we reviewed. The nature of access and rights to productive resource resources varies. As Meinzen-Dick et al. (2017) observe, literature on women's land rights often refers to use, control and ownership rights to land and the different components of rights these entail, ranging from the permission to employ and assets, through the power over management and exclusion, to full ownership including the right to use as collateral and sale. From the perspective of access of Ribot and Peluso (2003), the ability to derive benefits does not necessarily require full ownership.

Labour, or time, is often a constraint for women, due to their responsibility for household chores such as cooking and taking care of children, which limits the time they can spend on other tasks. At the same time, this so called reproductive labour is necessary also to sustain the formal economy, and many feminist economists have argued that it should be recognised as such (e.g. Hoskyns and Rai 2007; Power 2004). While women play an important part in agricultural production, it is also likely that their contribution to production activities are constrained by their responsibilities for household chores. As we will see below, these limits to women's time may lead them to look for production opportunities close to the homestead or with minimal requirements for labour input.

In relation to the marketization resources needed to earn income from produce, feminist economists emphasise that markets are gendered institutions, shaped by social relations (Benería et al. 2016; Elson
1993; Elson and Cagatay 2000). Harriss-White (2005), for example, shows that women's possibilities to benefit from market exchange are limited by gendered constraints to access to information, control over processing facilities, transport and productive resources. With this in mind, we review what the literature has to say about women's possibilities to benefit from commercialisation of their production in multifunctional landscapes.

\section{Materials and methods}

The following text is the result of a directed search based on a number of keywords (listed in Table 1), in two key databases (Scopus and Google Scholar), as well as websites of dedicated research institutes including ICRAF (World Agroforestry Centre) and CIFOR (Centre for International Forestry Research). A screening of abstracts was conducted to exclude a small number of obviously irrelevant posts. The search was also complemented with literature found in bibliographies of articles found in the initial searches, through backward reference list checking (Gough et al. 2012). Additional literature, already known by the authors, dealing with the themes of the review, but which did not come up in searches, was also added to the list. A list of the articles reviewed is included in the "Appendix". It is not meant as a systematic review of the literature available relating to gender and women in food production in multifunctional landscapes, but examines previous research findings based on the theoretical framework presented above.

A third of the 104 articles reviewed deal explicitly with issues of food security (Table 2). About half of the publications identified in our searches have a specific focus on gender and/or women. One quarter include women as a variable, but do not have it as a main focus, and the rest do not refer specifically to gender or women. Of the 104 publications reviewed, fifty-seven are focused on Africa, either specific countries or in a regional analysis. A quarter of the articles have a global scope, and the rest look at Asia or Latin America. Forty-two of the publications deal with forests and agroforestry systems, almost a quarter are about livestock systems, and the rest deal with agricultural systems, including homegardens, mixed crop systems, and urban agriculture. While we had initially planned to include in the analysis landscapes 
Table 1 Principal search terms

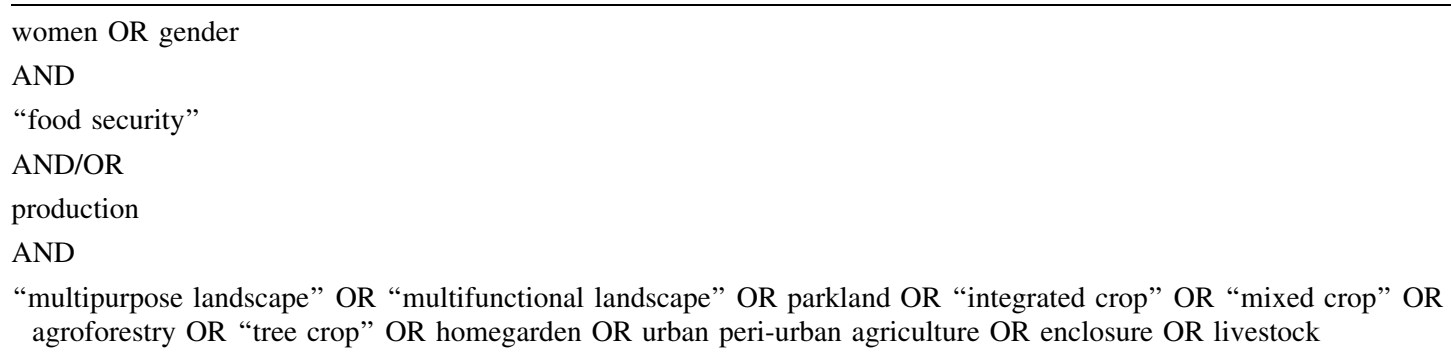

Table 2 Characteristics of the reviewed material
A full list of reviewed articles can be found in the "Appendix"

\begin{tabular}{lc}
\hline Thematic scope & Number of articles \\
\hline Food security & 35 \\
Gender or women & 52 \\
Women included but not in focused on women & 26 \\
Forestry or agroforestry & 42 \\
Livestock & 22 \\
Agricultural systems; homegardens, mixed crop systems & 40 \\
and urban agriculture & \\
Homegardens, mixed crop systems and urban agriculture & \\
Geographical focus & \\
Global scope & 26 \\
In Africa & 57 \\
In Asia or Latin America & 21 \\
Total number of articles reviewed & 104 \\
\hline
\end{tabular}

involved in climate change mitigation, the lack of relevant literature concerning food security and gender in such landscapes led to their non-inclusion.

\section{Productive resources}

Access, ownership and rights to land and trees

Ownership, user rights and other types of access to land and trees shape production opportunities for both men and women. In landscapes characterised by the presence of trees, including forest and agroforestry lands, such tenure and access rights are often complicated and multi-layered and structured by gender, ethnicity and other social relations, as shown in numerous case studies (e.g. Fortmann 1995; Rocheleau and Edmunds 1997; Rousseau et al. 2016; Westholm 2016).
In Sub-Saharan Africa, women's access to trees and their fruits, are often conditioned on their relationship to men, e.g. their husband, and they stand to lose access in case of divorce (Parrotta et al. 2015). This is the case in many parts of the world also for access to land (Lastarria-Cornhiel et al. 2014). Also in settings where community organisations are in charge of management and/or distribution of access rights, women's rights are often legitimated and mediated through their relation to men, including their husbands and male community leaders. In some countries, formal laws are more progressive in granting women land rights, and this can affect management practices. For example, several studies have shown that women with knowledge of their land rights are more likely to plant trees (Deininger et al. 2008; Quisumbing and Kumar 2014).

The limitations in women's access to land has led to a greater dependence on products from open access or 
low-value land. Non-timber forest products (NTFPs) are one type of product often subject to relatively open access. In many settings, women are the main collectors of such products (e.g. Ibnouf 2009; Shackleton et al. 2011; Westholm 2016). Sunderland et al. (2014) find that women dominate wild plant food collection in Asia and Africa, but not in Latin America. Several studies in Mai et al.'s (2011) review of gender analysis in forestry research, found that women's greater dependence on income from NTFPs was due to their limited access to alternative incomes. NTFPs are often considered secondary to the primary (male) products including agricultural crops or timber. Nevertheless, they provide an important source of food and contribute to the diversification of diets, which is important for food security.

Women's limited access to land also has effects for their practice of urban agriculture, the importance of which has grown in the context of rapid urbanisation, now constituting an important source of food and income for many poor people. Competition for land in urban areas is often fierce. Nabulo et al. (2009) found that women in Kampala, Uganda, due to their lack of ownership and control over land, were more likely than men to grow food crops on contaminated lands, making them vulnerable to health risks.

An alternative strategy to turning to marginal or open access products is seeking modes of production that require little land. One such example is smallscale poultry production, which requires little space or input from farmed land. In Africa, rural, small-scale poultry production contributes $20-30 \%$ of total animal protein intake, and is a source of important micronutrients (Wong et al. 2016). Extensive or semi-intensive poultry production, where chicken scavenge for food, or receive some supplementary feed is usually accessible also to the most marginalised groups at highest risk of food insecurity. Rearing and production, and the resulting food or income, is often controlled entirely by women (Wong et al. 2016), although in some contexts women play an important part in caring for the animals, but do not have full control over benefits gained, or decision-making about the use of birds and eggs (Guèye 2003). As we elaborate in the coming sections, the accessibility of poultry production is further enhanced by its limited requirement of other inputs.

Regardless of the overarching trends, women's customary tenure and use rights may be strong in some contexts, but due to their informal nature, they risk being overlooked and marginalised in the introduction of laws, policies or projects are introduced (Quisumbing et al. 2015; Stloukal et al. 2013). In her study of the formulation of a REDD+ program in Burkina Faso, Westholm (2016) found a lack of understanding among policy makers of the customary organisation of access to NTFPs, structured by ethnicity, due to the absence of women's voices in the policy process. This led her to warn that policies aimed at increasing their value risked marginalising certain women's use of shea and néré fruits and leading to increased conflicts and competition for these products. This underlines the importance of policies aimed at production, use and/or trade in forest and tree resources to be designed with awareness of, and sensitivity to, local, informal institutions and relations of power. Otherwise even policies that benefit some groups risk increasing food insecurity for others.

Control over labour and time; staying close to home

The organisation of labour and time is another important factor in shaping gendered roles in food production. Women's traditional responsibilities in the homestead, including cooking and childcare, often limits their possibilities to take on work far away from home. The multiple tasks demanding their time limit their possibilities to engage in additional time-consuming activities. As the literature shows women often find strategies to work around such limitations within traditional gender roles. For example, women have been found to own and/or manage small livestock or poultry to a larger extent than men, due to limited access to land and discussed above, but also due to such animals requiring less work, and that they can be kept close to the house (Galiè et al. 2015).

Poultry farming can easily be combined with other income-generating roles and household tasks, as shown for example by Hovorka (2006) in her study of women in low-income households in Gaborone, Botswana. Lacking access to commercial agricultural land, they managed to take advantage of the opportunities arising from operating poultry enterprises from their residential plots. By operating within their community, not in distant agricultural plots, they could more easily draw on support and linkages with their communities. The women managed to establish 
effective marketing channels within their residential areas, selling produce directly from their doorstep, thereby eliminating the need for storage, refrigeration and processing. This way, the disadvantage in terms of limited access to land and time constraints were drawn upon to their advantage. Hovorka (2012) writes that this development has enabled empowerment and new identities for women as independent, urban, entrepreneurs, rather than rural subsistence farmers and reproductive care takers.

In both urban and rural areas, homegardens, or backyard plots, are important to women's contribution to household food security. Ibnouf (2009) in a study in the Sudan, found that crop diversity in homegardens fully controlled by women is often greater than on the family fields, with crops including vegetables, beans and fruits. In Bangladesh women have also been found to play an important role in management and decisionmaking concerning homegardens (Akhter et al. 2010). Although homegarden management is not always a female activity, as Galhena et al. (2013) observe, the location in or near the homestead makes it easier to combine homegarden management with other household chores. In the Sudan, Ibnouf (2009) found that women's contribution to household food security is larger than men's, and the hours they spend on related activities longer. These activities can be undertaken close to the homestead, and include processing and preservation of agricultural and forest products in order to improve shelf life, thereby enhancing dietary diversity of the household.

Control over capital; the opportunity of small livestock

Gendered differences in control over, and ability to accumulate, capital also shape food production. Capital investments in food production can take many forms, including agricultural inputs and technology. Women's access to agricultural inputs is often more limited than for men, partly because they practice subsistence, rather than commercial agriculture, and therefore have less cash to spend. As shown by Cadzow and Binns (2016) in the case of urban agriculture in Sierra Leone, women often bear the main responsibility for paying household costs such as food, schooling and health expenses. This means that men have more possibilities for taking risks in their entrepreneurial endeavours. Galhena et al. (2013) note that homegardens not only provide opportunities for those with limited access to land and time, as discussed above, but can also enhance food security for those with limited capital. They show that crop production in homegardens is often integrated with livestock and/or poultry production.

Livestock is the main form of capital discussed in the literature we have reviewed. Assets in terms of livestock are often easier for women to acquire than land or other physical or financial assets (Kristjanson et al. 2014). As shown in studies from across the world, women invest in, and accumulate, capital in livestock. Although women are often considered more likely to own small livestock, gender roles and relations vary over between regions and cultures, and over time (Kristjanson et al. 2014: 213). In the West Pokot region in Kenya women have become more involved in management activities and decisions relating to livestock as processes of land enclosure have led to a shift from pastoralism to sedentary livestock keeping (Karmebäck et al. 2015).

In many contexts, women are more likely than men to acquire their livestock through non-market channels, as gifts, inheritance, or through development projects. The informality often characterising women's livestock ownership puts them at greater risk of losing their assets (Kristjanson et al. 2014). Efforts to formalise ownership may therefore be beneficial for women. In a study from Tanzania, Ethiopia and Nicaragua, Galiè et al. (2015) show that the understanding of ownership and access to livestock resources is shaped by a variety of layered arrangements of management and access to benefits. The lived experiences of ownership and distribution of resources revealed institutionalised gender bias in favour of men. As discussed above in relation to NTFPs, for policy makers or project developers aiming to enhance food security, understanding how such access to resources and benefits plays out in the local context is crucial in order to avoid adverse impacts. Similarly, Petitt (2016) shows that cattle ownership in Botswana does not simply follow the gender roles which associate cattle with men, but are intersected by a range of social categories such as ethnicity, race, class and marital status, which play an important role in shaping ownership and access patterns. She observes that it is sometimes easier for women without a predefined 'traditional' role in cattle production to 
obtain independent control as owners and managers of cattle (Petitt 2016: 215).

\section{Marketization resources; windows of opportunities}

Subsistence and household limits

The same gender inequalities that affect women's productivity in agriculture shape their performance in value chains (Rubin and Manfre 2014). Although explicit monetary values are rarely found in the literature, women have been found to derive a larger share of their income than men from NTFPs in case studies from different parts of the world (e.g. Ouedraogo et al. 2013), and in a global comparison by Sunderland et al. (2014). Nevertheless, men tend to collect a larger share of the income from sales of both processed and unprocessed forest products (Sunderland et al. 2014). Women's production in kitchen gardens and urban agricultural plots is often aimed at subsistence rather than commercialisation and plays an important role in feeding families (Hovorka et al. 2009). Planners tend to prioritise commercial production and overlook subsistence production. In order to support and enhance the contribution of urban homegardens to food security, there is a need for greater recognition from planners.

Women's possibilities for earning incomes from tree products are often constrained by the traditionally gender differentiated roles they are assigned in value chains. As discussed above in relation to land rights and NTFPs, men tend to control crops that are more easily marketable, or earn a higher market value. While women deal with retail trade, men are more often involved in wholesale trade (Kiptot et al. 2014). Elias and Arora-Jonsson (2016) show that although shea nut value chains in Burkina Faso provide income earning opportunities for some women, profits are often concentrated in the hands of wholesalers. Mai et al. (2011) found several studies showing that women's limited access to technology for processing forest products left them at a disadvantage in value chains, suggesting that promotion of technology and knowledge for women could promote their success as entrepreneurs.
Non-market channels

In addition, women risk being out-competed by men in market exchange, because men tend to have more control over assets required for benefiting from trade. Evidence of men taking over parts of a value chain as profitability increases, pushing out women, is available from multiple studies of NTFP trade (Belcher and Schreckenberg 2007; Ingram et al. 2014; Shackleton et al. 2011). In the context of fuelwood trade in southern Burkina Faso, Zougouri (2008) found that women lost opportunities and had worse bargaining positions, because their contacts with traders and wholesalers were often mediated by men. Similarly, Karmebäck et al. (2015) found that as poultry production in West Pokot, Kenya, became more commercialised, more men started to get involved as middlemen in poultry trade.

To maintain control over their products and sales, Saussey et al. (2008) have shown that women in Burkina Faso often retain a share of their Shea nuts, rather than selling them to Shea cooperatives, in order to sell them on the local market. In a similar vein, Arora-Jonsson (2013: 223-225) found that women in India opted out of the mainstream market, and instead chose to trade their bamboo goods with each other, in order to maintain control. There are also examples where new patterns of commercialisation have provided an opportunity for women, as shown by Petitt (2016) in the case of cattle ownership in Botswana. She observes that women's control over cattle was enabled by, as well as enabling, new gender relations. Changing gender relations resulting from broader economic and social processes made it easier for women to obtain access and control over cattle, a traditionally male resource.

One obstacle to women's market activities can be the traditional division between public and private space, where women's movement in public space is limited by societal norms which define a woman's place to be within the household. Social and economic processes my lead to a change in gendered norms. Karmebäck et al. (2015) found that the expansion of the monetary economy in Kenya prompted women to take greater part in market activities in order to earn income, and expanding their independence to move beyond the homestead. This led to women taking on roles in spaces previously unavailable to them. Thus, while gender inequalities constitute severe obstacles 
to women's opportunities, there are examples in the literature of how gender roles change and provide new openings for women. To reduce gender equality more broadly, however, policy action is needed.

Opportunities, challenges and recommendations

Multifunctional landscapes can provide opportunities for women to improve the food security and production for themselves and their families in a context of limited access to productive resources such as land, labour and capital inputs. However, the role of multifunctionality of landscapes for women's opportunities to enhance food security is rarely explicitly examined or discussed in scientific literature. We argue that by paying attention to the multifunctionality of landscapes it is possible to highlight the opportunities provided by a diversity of modes of production and products in a context of gender inequality. Wild plants and fruits from forests can constitute important complements to otherwise monotonous diets, and diversify incomes. Home gardening systems can provide sources of nutrients or income by allowing production to be combined with other household chores. Production of small livestock and poultry provide opportunities for producing food with relatively small requirements for land, labour or inputs.

Female products: secondary and low-value

As our review has highlighted, "female products" produced in multifunctional landscapes, such as NTFPs, are often of secondary importance or have a lower economic value than other products produced in the same landscapes. In addition, women's production of poultry, small livestock, or produce is often smallscale because of their limited access to land and capital, or due to time and labour constraints (e.g. Galhena et al. 2013; Galiè et al. 2015; Wong et al. 2016). They risk being disregarded in decisions related to land use or management or in policy making. Awareness of the range of products and services produced in multifunctional landscapes, and how access to, and decision-making about these products is organised, is key for policy makers aiming to enhance food security. Otherwise there is a risk that certain groups or products are marginalised by policy interventions, as Westholm's (2016) example from Burkina Faso showed.
Barriers to market entry

A range of studies from varying contexts, including NTFPs, fuelwood and poultry production, point to the risk that increased value of a product may lead to men, or other powerful groups, taking control of production or part of the value chain for commercialisation (e.g. Ingram et al. 2014; Karmebäck et al. 2015; Shackleton et al. 2011). While this is not always the case, it is a risk that needs to be taken seriously by policy makers in the formulation and implementation of policies aimed at empowering women by promoting processing and commercialisation of traditionally "female products".

Multiple opportunities in multifunctional landscapes?

This unstable nature of gender relations can work in women's favour. Notably, several examples in the literature of how changes in gender relations can come about in the context of changing external circumstances, such as urbanization, a shift from pastoralism to a sedentary way of life, or an expansion of the monetary economy (e.g. Hovorka 2006; Karmebäck et al. 2015; Petitt 2016). While such changes may imply a risk, as noted above, of women losing control or access over resources, it may also provide an opportunity for previously disadvantaged groups to seize power or control over resources, which were previously unavailable to them. Such opportunities may arise in contexts where traditional gender and power relations are disrupted by changing circumstances, providing opportunities to claim new roles and identities, beyond those traditionally available.

\section{Research gaps and conclusions}

We have identified a few areas where further research could increase the understanding of the nexus of gender and multifunctional land use for food security. First, there is little quantitative data on the role of multifunctional land use for food security and production, not least from a gender perspective and compared to other land uses. Secondly, explicit analysis of the monetary values of 'male' and 'female' products in multifunctional land use systems are scant. 
Finally, for women to become equal player in terms of availability, access, utilization and stability in food security and food production, there is a need for active and deliberate policy making. It is worth repeating that gender relations need to be analysed and understood in context to avoid adverse effects of policies. This relates both to the risks involved and the opportunities that interventions can bring about. There is also a need for awareness of the instability of gender roles, and how they may change in unexpected way as a result of policies or social processes. Finally, it is important to stress that in order to improve gender equality in any context, there is a need for social policy that allows women the basic security needed to make their own choices and take chances.

Funding This review was conducted as part of the AgriFoSe2030 program, which is funded by the Swedish International Development Agency (Sida) and hosted by the Swedish University of Agricultural Sciences.

\section{Compliance with ethical standards}

Conflict of interest The authors declare that they have no conflict of interest.

Open Access This article is distributed under the terms of the Creative Commons Attribution 4.0 International License (http:// creativecommons.org/licenses/by/4.0/), which permits unrestricted use, distribution, and reproduction in any medium, provided you give appropriate credit to the original author(s) and the source, provide a link to the Creative Commons license, and indicate if changes were made.

\section{Appendix: Articles reviewed}

Akhter S, Alamgir M, Sohel MSI, Rana MP, Monjurul Ahmed SJ, Chowdhury MSH (2010) The role of women in traditional farming systems as practiced in homegardens: A case study in Sylhet Sadar Upazila, Bangladesh Tropical Conservation Science 3:17-30

Almeida LS, Gama JRV (2014) Home gardens: Structure, floristic composition and environmental aspects in area of rural settlement in Brazil's amazon forest Ciencia Florestal 24:1037-1048

Arnold M, Powell B, Shanley P, Sunderland TCH (2011) EDITORIAL: Forests, Biodiversity and Food Security International Forestry Review 13:259-264 https://doi.org/10.1505/146554811798293962

Balasubramanian V, Sie M, Hijmans RJ, Otsuka K (2007) Increasing Rice Production in Sub-Saharan
Africa: Challenges and Opportunities vol 94. https:// doi.org/10.1016/s0065-2113(06)94002-4

Belcher B, Schreckenberg K (2007) Commercialisation of non-timber forest products: A reality check Development Policy Review 25:355-377

Bernholt H, Kehlenbeck K, Gebauer J, Buerkert A (2009) Plant species richness and diversity in urban and peri-urban gardens of Niamey, Niger Agroforestry Systems 77:159-179 https://doi.org/10.1007/s10457009-9236-8

Caballero-Serrano V, Onaindia M, Alday JG, Caballero D, Carrasco JC, McLaren B, Amigo J (2016) Plant diversity and ecosystem services in Amazonian homegardens of Ecuador Agriculture, Ecosystems and Environment 225:116-125 https:// doi.org/10.1016/j.agee.2016.04.005

Cadzow H, Binns T (2016) Are groups a good thing? Evaluating group associations among vegetable farmers in Freetown, Sierra Leone Development in Practice 26:406-419 https://doi.org/10.1080/ 09614524.2016 .1159662

Cadzow H, Binns T (2016) Empowering Freetown's women farmers Applied Geography 74:1-11 https://doi.org/10.1016/j.apgeog.2016.06.010

Colfer CJP, Catacutan D, Naz F (2015) Introduction: contributions and gaps in gender and agroforestry International Forestry Review 17:1-10 https://doi.org/ $10.1505 / 146554815816086471$

Crush J, Hovorka A, Tevera D (2011) Food security in Southern African cities Progress in Development Studies 11:285-305 https://doi.org/10.1177/ 146499341001100402

De Zeeuw H, Van Veenhuizen R, Dubbeling M (2011) The role of urban agriculture in building resilient cities in developing countries The Journal of Agricultural Science 149:153-163 https://doi.org/10. 1017/s0021859610001279

Devendra C, Chantalakhana C (2002) Animals, poor people and food insecurity: Opportunities for improved livelihoods through efficient natural resource management Outlook on Agriculture 31:161-175

Elias M, Arora-Jonsson S (2016) Negotiating across difference: Gendered exclusions and cooperation in the shea value chain Environment and Planning D: Society and Space https://doi.org/10.1177/ 0263775816657084

Evans R, Mariwah S, Barima Antwi K (2015) Struggles over family land? Tree crops, land and 
labour in Ghana's Brong-Ahafo region Geoforum 67:24-35 https://doi.org/10.1016/j.geoforum.2015. 10.006

Forsythe L, Martin A, Posthumus H (2015) Cassava market development: a path to women's empowerment or business as usual? Food Chain 5:11-27 https://doi.org/10.3362/2046-1887.2015.003

Fouladbash L, Currie WS (2015) Agroforestry in Liberia: household practices, perceptions and livelihood benefits Agroforestry Systems 89:247-266 https://doi.org/10.1007/s10457-014-9763-9

Franzel S, Carsan S, Lukuyu B, Sinja J, Wambugu C (2014) Fodder trees for improving livestock productivity and smallholder livelihoods in Africa Current Opinion in Environmental Sustainability 6:98-103 doi:https://doi.org/10.1016/j.cosust.2013. 11.008

Gabrielsson S, Ramasar V (2013) Widows: Agents of change in a climate of water uncertainty Journal of Cleaner Production 60:34-42 https://doi.org/10.1016/ j.jclepro.2012.01.034

Galhena DH, Freed R, Maredia KM (2013) Home gardens: a promising approach to enhance household food security and wellbeing Agriculture \& Food Security 2:8 https://doi.org/10.1186/2048-7010-2-8

Galiè A, Mulema A, Mora Benard MA, Onzere SN, Colverson KE (2015) Exploring gender perceptions of resource ownership and their implications for food security among rural livestock owners in Tanzania, Ethiopia, and Nicaragua Agriculture and Food Security 4 https://doi.org/10.1186/s40066-015-0021-9

Goenster S, Wiehle M, Kehlenbeck K, Jamnadass R, Gebauer J, Buerkert A (2011) Indigenous fruit trees in homegardens of the Nuba Mountains, Central Sudan: Tree diversity and potential for improving the nutrition and income of rural communities vol 911

Graef F et al. (2015) Natural resource management and crop production strategies to improve regional food systems in Tanzania Outlook on Agriculture 44:159-167 https://doi.org/10.5367/oa.2015.0206

Guarascio F, Gunewardena N, Holding C, Kaaria S, Stloukal L (2013) Forests, food security and gender: linkages, disparities and priorities for action. FAO, Rome

Guèye EF (2003) Gender issues in family poultry production systems in low-income food-deficit countries American Journal of Alternative Agriculture 18:185-195 https://doi.org/10.1079/ajaa200350
Gyau A, Franzel S, Chiatoh M, Nimino G, Owusu K (2014) Collective action to improve market access for smallholder producers of agroforestry products: key lessons learned with insights from Cameroon's experience Current Opinion in Environmental Sustainability 6:68-72 doi:https://doi.org/10.1016/j. cosust.2013.10.017

Hanjra MA, Iqbal Zafar M, Batool Z, Nawaz N, Maann AA, Ayalew Z, Alemu BA (2013) Gender mainstreaming for food security and poverty reduction programs in Asia and Africa. In: Global Food Security: Emerging Issues and Economic Implications, pp 245-272

Howard PL (2006) Gender and social dynamics in swidden and homegardens in Latin America. In: Kumar BM, Nair PKR (eds) Tropical Homegardens: A Time-Tested Example of Sustainable Agroforestry. Springer, Netherlands, pp 159-182

Howard PL, Nabanoga G (2007) Are there Customary Rights to Plants? An Inquiry among the Baganda (Uganda), with Special Attention to Gender World Development 35:1542-1563 doi:https://doi. org/10.1016/j.worlddev.2006.05.021

Hovorka A, de Zeeuw H, Njenga M (2009) Women feeding cities: Mainstreaming gender in urban agriculture and food security. Technical Centre for Agricultural and Rural Cooperation,

Hovorka AJ (2006) The No. 1 Ladies' Poultry Farm: A feminist political ecology of urban agriculture in Botswana Gender, Place \& Culture 13:207-225 https://doi.org/10.1080/09663690600700956

Hovorka AJ (2006) Urban agriculture: addressing practical and strategic gender needs Development in Practice 16:51-61 https://doi.org/10.1080/ 09614520500450826

Hovorka AJ (2012) Women/chickens vs. men/cattle: Insights on gender-species intersectionality Geoforum 43:875-884 doi:https://doi.org/10.1016/j. geoforum.2012.02.005

Ibnouf FO (2009) The role of women in providing and improving household food security in Sudan: Implications for reducing hunger and malnutrition Journal of International Women's Studies 10:144-167

Inoni OE, Chukwuji CO, Ogisi OD, Oyaide WJ (2007) Alleviating rural poverty: What role for smallholder livestock production in Delta State, Nigeria Agriculturae Conspectus Scientificus 72:159-164

Kariuki J, Njuki J, Mburu S, Waithanji E (2013) Women, livestock ownership and food security. In: 
Women, Livestock Ownership and Markets: Bridging the gender gap in Eastern and Southern Africa, pp 95-110. https://doi.org/10.4324/9780203083604

Karmebäck VN, Wairore JN, Jirström M, Nyberg G (2015) Assessing gender roles in a chaning landscape: diversified agro-pastoralism in drylands of West Pokot, Kenya Pastoralism 5 https://doi.org/10.1186/ s13570-015-0039-4

Kiptot E (2015) Gender roles, responsibilities, and spaces: implications for agroforestry research and development in Africa International Forestry Review 17:11-21 https://doi.org/10.1505/ 146554815816086426

Kiptot E, Franzel S, Degrande A (2014) Gender, agroforestry and food security in Africa Current Opinion in Environmental Sustainability 6:104-109 https://doi.org/10.1016/j.cosust.2013.10.019

Kristjanson P et al. (2014) Livestock and Women's Livelihoods. In: Quisumbing AR, Meinzen-Dick R, Raney TL, Croppenstedt A, Behrman JA, Peterman A (eds) Gender in Agriculture: Closing the Knowledge Gap. Springer Netherlands, Dordrecht, pp 209-233. https://doi.org/10.1007/978-94-017-8616-4_9

Kumar BM, Nair PKR (2004) The enigma of tropical homegardens. In: Nair PKR, Rao MR, Buck LE (eds) New Vistas in Agroforestry: A Compendium for 1st World Congress of Agroforestry, 2004. Springer Netherlands, Dordrecht, pp 135-152. https://doi.org/10.1007/978-94-017-2424-1_10

Kustantinah A, Hartadi H, Suhartanto B, Utomo R, Yusiati LM, Agus A, Ørskov ER (2011) Role of women in ensuring adequate food security in Indonesia: Lessons to be learned Livestock Research for Rural Development 23

Lacombe N (2015) The genderization of agricultural activities in the arganeraie (Morocco). The « breeder» and the «breaker» as social figures of family farming deconstruction Bulletin d'Association de Geographes Francais 92:364-384

Lasco RD, Delfino RJP, Catacutan DC, Simelton ES, Wilson DM (2014) Climate risk adaptation by smallholder farmers: the roles of trees and agroforestry Current Opinion in Environmental Sustainability 6:83-88 doi:https://doi.org/10.1016/j.cosust. 2013.11.013

Leakey RR (2010) Agroforestry: a delivery mechanism for multi-functional agriculture. In: Kellimore LR (ed) Handbook on agroforestry: management practices and environmental impact. Nova Science Publishers, pp 461-471

Lee-Smith D (2010) Cities feeding people: an update on urban agriculture in equatorial Africa Environment and Urbanization 22:483-499 https:// doi.org/10.1177/0956247810377383

Lerner AM, Eakin H (2011) An obsolete dichotomy? Rethinking the rural-urban interface in terms of food security and production in the global south The Geographical Journal 177:311-320 https://doi.org/10. 1111/j.1475-4959.2010.00394.x

Loos J, Abson DJ, Chappell MJ, Hanspach J, Mikulcak F, Tichit M, Fischer J (2014) Putting meaning back into "sustainable intensification" Frontiers in Ecology and the Environment 12:356-361 https://doi.org/10.1890/130157

Maconachie R, Binns T, Tengbe P (2012) Urban farming associations, youth and food security in postwar Freetown, Sierra Leone Cities 29:192-200 https:// doi.org/10.1016/j.cities.2011.09.001

Maldonado Villavicencio L (2009) Urban agriculture as a livelihood strategy in Lima, Peru. In: Redwood M (ed) Agriculture in urban planning. Generating livelihoods and food security. Earthscan, London, pp 49-72

Mason R, Ndlovu P, Parkins JR, Luckert MK (2015) Determinants of food security in Tanzania: gendered dimensions of household headship and control of resources Agriculture and Human Values 32:539-549 https://doi.org/10.1007/s10460-0149568-5

Mattsson E, Ostwald M, Nissanka SP (2017) What is good about Sri Lankan homegardens with regards to food security? A synthesis of the current scientific knowledge of a multifunctional land-use system Agroforestry Systems https://doi.org/10.1007/ s10457-017-0093-6

Mbow C, van Noordwijk M, Prabhu R, Simons T (2014) Knowledge gaps and research needs concerning agroforestry's contribution to Sustainable Development Goals in Africa Current Opinion in Environmental Sustainability 6:162-170 doi:https:// doi.org/10.1016/j.cosust.2013.11.030

McKune SL et al. (2015) Climate change through a gendered lens: Examining livestock holder food security Global Food Security 6:1-8 https://doi.org/ 10.1016/j.gfs.2015.05.001

Meinzen-Dick RS, Brown LR, Feldstein HS, Quisumbing AR (1997) Gender, property rights, and 
natural resources World Development 25:1303-1315 doi:https://doi.org/10.1016/S0305-750X(97)00027-2

Mkwambisi DD, Fraser EDG, Dougill AJ (2011) Urban agriculture and poverty reduction: Evaluating how food production in cities contributes to food security, employment and income in Malawi Journal of International Development 23:181-203 https://doi. org/10.1002/jid.1657

Moore EA, Munsell JF, Hammett ALT, Moore KM (2014) Agroforestry preferences in refugee hosting communities in Cameroon Agroforestry Systems 88:735-752 https://doi.org/10.1007/s10457-0149695-4

Msangi JP (2014) Urban, Peri-urban Agriculture and Food Security Among Small-Scale Agricultural Producers: Southern Africa. In: Food Security Among Small-Scale Agricultural Producers in Southern Africa. Springer International Publishing, Cham, pp 43-74. https://doi.org/10.1007/978-3-319-094953_3

Nabulo G, Kiguli J, Kiguli LN (2009) Gender in urban food production in hazardous areas in Kampala, Uganda. In: Hovorka A, De Zeeuw H, Njenga M (eds) Women feeding cities: Mainstreaming gender in urban agriculture and food security. Technical Centre for Agricultural and Rural Cooperation, pp 81-94

Ndayambaje JD, Heijman WJM, Mohren GMJ (2012) Household Determinants of Tree Planting on Farms in Rural Rwanda Small-scale Forestry 11:477-508 https://doi.org/10.1007/s11842-0129196-0

Njuki J, Sanginga PC (2013) Women, livestock ownership and markets: Bridging the gender gap in eastern and Southern Africa. Women, Livestock Ownership and Markets: Bridging the gender gap in Eastern and Southern Africa. https://doi.org/10.4324/ 9780203083604

Nyantakyi-Frimpong H, Bezner Kerr R (2017) Land grabbing, social differentiation, intensified migration and food security in northern Ghana Journal of Peasant Studies 44:421-444 https://doi.org/10. 1080/03066150.2016.1228629

Nyongesa D, Esilaba AO, Emongor R, Bikketi E, Were K (2017) Assessment of gender and innovations in climatesmart agriculture for food and nutrition security in Kenya: A case of Kalii watershed International Journal of Agricultural Resources, Governance and Ecology 13:109-137 https://doi.org/10.1504/ ijarge.2017.086434
Oduol JBA, Mithöfer D, Place F, Nang'ole E, Olwande J, Kirimi L, Mathenge M (2017) Women's participation in high value agricultural commodity chains in Kenya: Strategies for closing the gender gap Journal of Rural Studies 50:228-239 doi:https://doi. org/10.1016/j.jrurstud.2017.01.005

Ouedraogo M, Ouedraogo D, Thiombiano T, Hien M, Lykke AM (2013) Economic dependence on nontimber forest products: the case of households in riparian forests of Bolt and Koflande in southwestern Burkina Faso Journal of Agriculture and Environment for International Development 107:45-72

Ofori DA, Gyau A, Dawson IK, Asaah E, Tchoundjeu Z, Jamnadass R (2014) Developing more productive African agroforestry systems and improving food and nutritional security through tree domestication Current Opinion in Environmental Sustainability 6:123-127 doi:https://doi.org/10.1016/j.cosust.2013. 11.016

Olawepo RA, Fatulu B (2012) Rural women farmers and food productivity in Nigeria: An example from Ekiti Kwara, Nigeria Asian Social Science 8:108-117 https://doi.org/10.5539/ass.v8n10p108

Parrotta JA, Dey de Pryck J, Darko Obiri B, Padoch C, Powell B, Sandbrook C (2015) The Historical, Environmental and Socio-economic Context of Forests and Tree-based Systems for Food Security and Nutrition. In: Vira B, Wildburger C, Mansourian S (eds) Forests and food. Addressing hunger and nutrition across sustainable landscapes. Open Book Publishers, Cambridge, UK,

Petitt A (2016) Women's cattle ownership in Botswana. Rebranding gender relations? Doctoral thesis, Swedish University of Agricultural Sciences

Quisumbing AR et al. (2015) Gender, assets, and market-oriented agriculture: learning from high-value crop and livestock projects in Africa and Asia Agriculture and Human Values 32:705-725 https:// doi.org/10.1007/s10460-015-9587-X

Rahman SA, Imam MH, Snelder DJ, Sunderland T (2012) Agroforestry for Livelihood Security in Agrarian Landscapes of the Padma Floodplain in Bangladesh Small-scale Forestry 11:529-538 https://doi.org/ 10.1007/s11842-012-9198-y

Rogé P et al. (2017) Perennial grain crops in the West Soudanian Savanna of Mali: perspectives from agroecology and gendered spaces International Journal of Agricultural Sustainability 15:555-574 https:// doi.org/10.1080/14735903.2017.1372850 
Roncoli C, Ingram K, Kirshen P (2001) The costs and risks of coping with drought: Livelihood impacts and farmers' responses in Burkina Faso Climate Research 19:119-132

Ros-Tonen MAF, Van Leynseele Y-PB, Laven A, Sunderland T (2015) Landscapes of Social Inclusion: Inclusive Value-Chain Collaboration Through the Lenses of Food Sovereignty and Landscape Governance The European Journal of Development Research 27:523-540 https://doi.org/10.1057/ejdr. 2015.50

Rousseau K, Gautier D, Wardell DA (2016) Renegotiating Access to Shea Trees in Burkina Faso: Challenging Power Relationships Associated with Demographic Shifts and Globalized Trade Journal of Agrarian Change:n/a-n/a https://doi.org/10.1111/joac. 12198

Roy MM (2016) Agroforestry on dry and degraded lands: Present status and future prospects Range Management and Agroforestry 37:1-11

Rubin D, Manfre C (2014) Promoting genderequitable agricultural value chains: Issues, Opportunities, and Next Steps. In: Quisumbing AR, MeinzenDick R, Raney TL, Croppenstedt A, Behrman JA, Peterman A (eds) Gender in Agriculture. Springer, Dordrecht, pp 287-313

Saussey M, Moity-Maizi P, Muchnik J (2008) Nouvelles formes de reconnaissance des femmes burkinabè dans la production collective de beurre de karité Cahiers Agricultures 17:582-586 https://doi. org/10.1684/agr.2008.0252

Shackleton S, Paumgarten F, Kassa H, Husselman M, Zida M (2011) Opportunities for enhancing poor women's socio-economic empowerment in the value chains of three African non-timber forest products (NTFPs) International Forestry Review 13:136-151

Simiyu RR, Foeken D (2013) I'm only allowed to sell milk and eggs': Gender aspects of urban livestock keeping in Eldoret, Kenya Journal of Modern African Studies 51:577-603 https://doi.org/10.1017/ s0022278x1300061x

Sinn R, Ketzis J, Chen T (1999) The role of woman in the sheep and goat sector Small Ruminant Research 34:259-269 https://doi.org/10.1016/s09214488(99)00078-4

Sonaiya EB (2007) Family poultry, food security and the impact of HPAI World's Poultry Science Journal 63:132-138 https://doi.org/10.1079/ wps2006135
Stloukal L, Holding C, Kaaria S, Guarascio F, Gunewardena N (2013) Forests, food security and gender Unasylva 64:37-45

Sunderland TCH (2011) Food Security: Why is Biodiversity Important? International Forestry Review 13:265-274 https://doi.org/10.1505/ 146554811798293908

Talukder A et al. (2010) Homestead food production model contributes to improved household food security and nutrition status of young children and women in poor populations Field Actions Science Reports [Online]

Tesfaye W, Seifu L (2016) Climate change perception and choice of adaptation strategies: Empirical evidence from smallholder farmers in east Ethiopia International Journal of Climate Change Strategies and Management 8:253-270 https://doi.org/10.1108/ ijccsm-01-2014-0017

Thangata PH, Hildebrand PE, Gladwin CH (2002) Modeling agroforestry adoption and household decision making in Malawi African Urban Quarterly 6:249-268

Thangata PH, Hildebrand PE, Kwesiga F (2007) Predicted impact of HIV/AIDS on improved fallow adoption and rural household food security in Malawi Sustainable Development 15:205-215 https://doi.org/ 10.1002/sd.323

Toth GG, Nair PKR, Duffy CP, Franzel SC (2017) Constraints to the adoption of fodder tree technology in Malawi Sustainability Science: 1-16 https://doi. org/10.1007/s11625-017-0460-2

Valdivia C (2001) Gender, livestock assets, resource management, and food security: Lessons from the SR-CRSP Agriculture and Human Values 18:27-39

Wan M, Colfer CJP, Powell B (2011) Forests, women and health: opportunities and challenges for conservation International Forestry Review 13:369-387 https://doi.org/10.1505/ 146554811798293854

van Noordwijk M, Bizard V, Wangpakapattanawong P, Tata HL, Villamor GB, Leimona B (2014) Tree cover transitions and food security in Southeast Asia Global Food Security 3:200-208 doi:https://doi. org/10.1016/j.gfs.2014.10.005

Van Veenhuizen R (2011) Inclusive, greenand productive cities. The role of urban agriculture Journal of Environmental Protection and Ecology 12:1470-1483 
Vermeulen S et al. (2012) Climate change, agriculture and food security: a global partnership to link research and action for low-income agricultural producers and consumers Current Opinion in Environmental Sustainability 4:128-133 doi:https://doi.org/ 10.1016/j.cosust.2011.12.004

Westholm L (2016) Fruits from the forest and the fields: Forest conservation policies and intersecting social inequalities in Burkina Faso's REDD+ program. International Forestry Review 18:511-521 https://doi.org/10.1505/146554816820127578

Villamor GB, van Noordwijk M (2016) Gender specific land-use decisions and implications for ecosystem services in semi-matrilineal Sumatra Global Environmental Change 39:69-80 doi:https://doi. org/10.1016/j.gloenvcha.2016.04.007

Villamor GB, van Noordwijk M, Djanibekov U, Chiong-Javier ME, Catacutan D (2014) Gender differences in land-use decisions: shaping multifunctional landscapes? Current Opinion in Environmental Sustainability 6:128-133 https://doi.org/10.1016/j. cosust.2013.11.015

Vinceti B, Ickowitz A, Powell B, Kehlenbeck K, Termote C, Cogill B, Hunter D (2013) The contribution of forests to sustainable diets. FAO, Rome

Vira B et al. (2015) Forests, Trees and Landscapes for Food Security and Nutrition. Forests and Food: Addressing Hunger and Nutrition Across Sustainable Landscapes. Open Book Publishers, Cambridge, UK

Wong JT, de Bruyn J, Bagnol B, Grieve H, Li M, Pym R, Alders RG (2016) Small-scale poultry and food security in resource-poor settings: A review Global Food Security https://doi.org/10.1016/j.gfs. 2017.04.003

Yiridoe EK, Anchirinah VM (2007) Garden production systems and food security in Ghana: Characteristics of traditional knowledge and management systems Renewable Agriculture and Food Systems 20:168-180 https://doi.org/10.1079/raf2005112

Yisehak K (2008) Gender responsibility in smallholder mixed crop-livestock production systems of Jimma zone, South West Ethiopia Livestock Research for Rural Development 20

\section{References}

Agarwal B (1997) "Bargaining" and gender relations: Within and beyond the household. Fem Econ 3:1-51

Akhter S, Alamgir M, Sohel MSI, Rana MP, Monjurul Ahmed SJ, Chowdhury MSH (2010) The role of women in traditional farming systems as practiced in homegardens: a case study in Sylhet Sadar Upazila, Bangladesh. Trop Conserv Sci 3:17-30

Arora-Jonsson S (2013) Gender, development and environmental governance: theorizing connections. Routledge, London

Belcher B, Schreckenberg K (2007) Commercialisation of nontimber forest products: a reality check. Dev Policy Rev 25:355-377

Benería L, Berik G, Floro MS (2016) Gender, development and globalization. Economics as if all people mattered, 2nd edn. Routledge, New York

Bustamante $\mathrm{M}$ et al (2014) Co-benefits, trade-offs, barriers and policies for greenhouse gas mitigation in the agriculture, forestry and other land use (AFOLU) sector. Glob Change Biol 20:3270-3290

Cadzow H, Binns T (2016) Empowering Freetown's women farmers. Appl Geogr 74:1-11. https://doi.org/10.1016/j. apgeog.2016.06.010

Deininger K, Ali DA, Yamano T (2008) Legal knowledge and economic development: the case of land rights in Uganda. Land Econ 84:593-619. https://doi.org/10.3368/le.84.4. 593

Doss C (2013) Intrahousehold bargaining and resource allocation in developing countries. World Bank Res Obs 28:52-78. https://doi.org/10.1093/wbro/lkt001

Elias M, Arora-Jonsson S (2016) Negotiating across difference: gendered exclusions and cooperation in the shea value chain. Environ Plan D Soc Space. https://doi.org/10.1177/ 0263775816657084

Elson D (1993) Gender-aware analysis and development economics. J Int Dev 5:237-247

Elson D, Cagatay N (2000) The social content of macroeconomic policies. World Dev 28:1347-1364

FAO (2008) An introduction to the basic concepts of food security. FAO Food security programme. www.foodsec. org/docs/concepts_guide.pdf. Accessed 15 June 2018

Fortmann L (1995) Talking claims: discursive strategies in contesting property. World Dev 23:1053-1063. https://doi. org/10.1016/0305-750X(95)00024-7

Galhena DH, Freed R, Maredia KM (2013) Home gardens: a promising approach to enhance household food security and wellbeing. Agric Food Secur 2:8. https://doi.org/10. 1186/2048-7010-2-8

Galiè A, Mulema A, Mora Benard MA, Onzere SN, Colverson KE (2015) Exploring gender perceptions of resource ownership and their implications for food security among rural livestock owners in Tanzania, Ethiopia, and Nicaragua. Agric Food Secur. https://doi.org/10.1186/s40066015-0021-9

Gough D, Oliver S, Thomas J (2012) An introduction to systematic reviews. SAGE Publications, London 
Guèye EF (2003) Gender issues in family poultry production systems in low-income food-deficit countries. Am J Altern Agric 18:185-195. https://doi.org/10.1079/AJAA200350

Harriss-White B (2005) Female and male grain marketing systems. Analytical and policy issued for West Africa and India. In: Jackson C, Pearson R (eds) Feminist visions of development: gender analysis and policy. Taylor and Francis, Hoboken, pp 190-215

Hoskyns C, Rai SM (2007) Recasting the global political economy: counting women's unpaid work. New Polit Econ 12:297-317. https://doi.org/10.1080/13563460701485268

Hovorka AJ (2006) The No. 1 Ladies' Poultry Farm: a feminist political ecology of urban agriculture in Botswana. Gend Place Cult 13:207-225. https://doi.org/10.1080/ 09663690600700956

Hovorka AJ (2012) Women/chickens vs. men/cattle: insights on gender-species intersectionality. Geoforum 43:875-884. https://doi.org/10.1016/j.geoforum.2012.02.005

Hovorka A, de Zeeuw H, Njenga M (2009) Women feeding cities: mainstreaming gender in urban agriculture and food security. Technical Centre for Agricultural and Rural Cooperation

Ibnouf FO (2009) The role of women in providing and improving household food security in Sudan: implications for reducing hunger and malnutrition. J Int Women's Stud 10:144-167

Ingram V, Schure J, Tieguhong JC, Ndoye O, Awono A, Iponga DM (2014) Gender implications of forest product value chains in the Congo basin. For Trees Livelihoods 23:67-86

Kabeer N (1991) Gender, production and well-being: rethinking the household economy. Institute of Development Studies, Brighton

Kabeer N (1999) Resources, agency, achievements: reflections on the measurement of women's empowerment. Dev Change 30:435-464

Karmebäck VN, Wairore JN, Jirström M, Nyberg G (2015) Assessing gender roles in a changing landscape: diversified agro-pastoralism in drylands of West Pokot, Kenya. Pastoralism. https://doi.org/10.1186/s13570-015-0039-4

Kiptot E, Franzel S, Degrande A (2014) Gender, agroforestry and food security in Africa. Curr Opin Environ Sustain 6:104-109. https://doi.org/10.1016/j.cosust.2013.10.019

Kristjanson P et al (2014) Livestock and women's livelihoods. In: Quisumbing AR, Meinzen-Dick R, Raney TL, Croppenstedt A, Behrman JA, Peterman A (eds) Gender in agriculture: closing the knowledge gap. Springer, Dordrecht, pp 209-233. https://doi.org/10.1007/978-94-0178616-4_9

Lastarria-Cornhiel S, Behrman JA, Meinzen-Dick R, Quisumbing AR (2014) Gender equity and land: Toward secure and effective access for rural women. In: Quisumbing AR, Meinzen-Dick R, Raney TL, Croppenstedt A, Behrman JA, Peterman A (eds) Gender in agriculture. Closing the knowledge gap. Springer, Dordrecht, pp 117-144

Mai YH, Mwangi E, Wan M (2011) Gender analysis in forestry research: looking back and thinking ahead. Int For Rev 13:245-258. https://doi.org/10.1505/14655481179740 6589
Mander U, Helming K, Wiggering H (2007) Multifunctional land use: meeting future demands for landscape goods and services. Springer, Dordrecht

Mbow C, Smith P, Skole D, Duguma L, Bustamante M (2014) Achieving mitigation and adaptation to climate change through sustainable agroforestry practices in Africa. Curr Opin Environ Sustain 6:8-14

Meinzen-Dick R, Quisumbing A, Doss C, Theis S (2017) Women's land rights as a pathway to poverty reduction: Framework and review of available evidence. Agric Syst. https://doi.org/10.1016/j.agsy.2017.10.009

Nabulo G, Kiguli J, Kiguli LN (2009) Gender in urban food production in hazardous areas in Kampala, Uganda. In: Hovorka A, De Zeeuw H, Njenga M (eds) Women feeding cities: mainstreaming gender in urban agriculture and food security. Technical Centre for Agricultural and Rural Cooperation, Wageningen, pp 81-94

Ouedraogo M, Ouedraogo D, Thiombiano T, Hien M, Lykke AM (2013) Economic dependence on non-timber forest products: the case of households in riparian forests of Bolt and Koflande in southwestern Burkina Faso. J Agric Environ Int Dev 107:45-72

Parrotta JA, Dey de Pryck J, Darko Obiri B, Padoch C, Powell B, Sandbrook C (2015) The historical, environmental and socio-economic context of forests and tree-based systems for food security and nutrition. In: Vira B, Wildburger C, Mansourian S (eds) Forests and food. Addressing hunger and nutrition across sustainable landscapes. Open Book Publishers, Cambridge

Petitt A (2016) Women's cattle ownership in Botswana. Rebranding gender relations? Doctoral thesis, Swedish University of Agricultural Sciences

Power M (2004) Social provisioning as a starting point for feminist economics. Fem Econ 10:3-19. https://doi.org/10. 1080/1354570042000267608

Quisumbing AR, Kumar N (2014) Land rights knowledge and conservation in rural ethiopia - mind the gender gap. IFPRI discussion paper 01386

Quisumbing AR, Meinzen-Dick R, Raney TL, Croppenstedt A, Behrman JA, Peterman A (eds) (2014) Gender in agriculture. Closing the knowledge gap. Springer, FAO, IFPRI, Dordrecht

Quisumbing AR et al (2015) Gender, assets, and market-oriented agriculture: learning from high-value crop and livestock projects in Africa and Asia. Agric Hum Values 32:705-725. https://doi.org/10.1007/s10460-015-9587-x

Ribot JC, Peluso NL (2003) A theory of access*. Rural Sociol 68:153-181. https://doi.org/10.1111/j.1549-0831.2003. tb00133.x

Rocheleau D, Edmunds D (1997) Women, men and trees: gender, power and property in forest and agrarian landscapes. World Dev 25:1351-1371

Rousseau K, Gautier D, Wardell DA (2016) Renegotiating access to shea trees in Burkina Faso: challenging power relationships associated with demographic shifts and globalized trade. J Agrar Change. https://doi.org/10.1111/ joac. 12198

Rubin D, Manfre C (2014) Promoting gender-equitable agricultural value chains: issues, opportunities, and next steps. In: Quisumbing AR, Meinzen-Dick R, Raney TL, 
Croppenstedt A, Behrman JA, Peterman A (eds) Gender in agriculture. Springer, Dordrecht, pp 287-313

Saussey M, Moity-Maizi P, Muchnik J (2008) Nouvelles formes de reconnaissance des femmes burkinabè dans la production collective de beurre de karité. Cah Agric 17:582-586. https://doi.org/10.1684/agr.2008.0252

Sen AK (1990) Gender and cooperative conflicts. In: Tinker I (ed) Persistent inequalities. Women and world development. Oxford University Press, Oxford, pp 123-149

Shackleton S, Paumgarten F, Kassa H, Husselman M, Zida M (2011) Opportunities for enhancing poor women's socioeconomic empowerment in the value chains of three African non-timber forest products (NTFPs). Int For Rev 13:136-151

Stloukal L, Holding C, Kaaria S, Guarascio F, Gunewardena N (2013) Forests, food security and gender. Unasylva 64:37-45

Sunderland T et al (2014) Challenging perceptions about men, women, and forest product use: a global comparative study.
World Dev 64(Supplement 1):S56-S66. https://doi.org/10. 1016/j.worlddev.2014.03.003

Westholm L (2016) Fruits from the forest and the fields: forest conservation policies and intersecting social inequalities in Burkina Faso's REDD+ program. Int For Rev 18:511-521. https://doi.org/10.1505/146554816820127578

Wong JT, de Bruyn J, Bagnol B, Grieve H, Li M, Pym R, Alders RG (2016) Small-scale poultry and food security in resource-poor settings: a review. Glob Food Secur. https:// doi.org/10.1016/j.gfs.2017.04.003

Zougouri S (2008) Derrière la vitrine du développement. Aménagement forestier et pouvoir local au Burkina Faso. Uppsala University, Uppsala

Publisher's Note Springer Nature remains neutral with regard to jurisdictional claims in published maps and institutional affiliations. 